\title{
Accounting for Cross-border Mergers and Its Problems ${ }^{\#}$
}

\author{
Hana VOMÁČKOVÁ*
}

So called cross-border mergers have become a phenomenon of legal mergers in recent years.

De facto, this involves the merger of two or more legally independent companies where at least one company has its registered office in a different EU member state than the other participating companies. The legal successor may have its registered office in any EU member state.

The initial initiative is in Directive 2005/56/EC of the European Parliament and of the Council of 26 October 2005 on cross-border mergers of limited liability companies. EU member states were obliged to transpose this directive into their national commercial law not later than on 15 December 2005. There is no doubt that the purpose of this directive was to support and regulate mergers by allowing mergers of companies from various EU member states and, simultaneously, to support the concentration of legal power within the EU. In the Czech Republic this directive was reflected in Act No. 125/2008 Coll., regulating Transformations of Business Companies and Cooperatives.

\section{Both European and national legislation assume the following:}

a) Participating companies exist from a legal point of view and they function as accounting units and tax subjects under both national commercial and national accounting legislation, e.g. if a crossborder merger of a joint stock-company from the Czech Republic and the Slovak Republic is to be implemented, then both of the

\footnotetext{
\# The article is processed as an output of a research project Development of Financial and Accounting Theory and its Application in Practice from Interdisciplinary Point of View (registered number MSM 6138439903).

Prof. Ing. Hana Vomáčková, CSc. - professor; Department of Financial Accounting and Auditing, Faculty of Finance and Accounting, University of Economics, Prague, W. Churchill Sq. 4, 13067 Prague 3, Czech Republic; <vomackov @ vse.cz>.
} 
participating companies exist under the legal, accounting and tax legislation of their respective countries;

b) The final and decisive role is then played by the commercial, accounting and tax legislation of that EU member state in which the legal successor has its registered office after the merger. For example, if a legal successor is to have its registered office in the Czech Republic, the decisive commercial, accounting and tax legislation is that which is valid in the Czech Republic.

In other words, the originally participating companies exist as both legal subjects and accounting units under their national legislation, in the said case one under Czech legislation and the other under Slovak legislation. After a merger is implemented, the legal successor follows the legislation valid in the member state of its registered office. If the legal successor has its registered office in the Czech Republic, the liquidated company, for the purpose of the merger, has to be transferred - modified to the commercial, accounting and tax legislation valid in the Czech Republic.

Theoretically, no unusual problems should arise if EU directives exist which unify commercial law, e.g. the directive on cross-border mergers of limited liability companies (see above), accounting directives, e.g. IFRS 3 Business Combinations which was adopted by Regulation (EC) No. 1606/2002 of the European Parliament and of the Council and, as a basis of accounting legislation for business combination, COUNCIL DIRECTIV 2005/19/EC of 17 February 2005 amending Directive 90/434/EEC 1990 on the common system of taxation in order to prevent obtaining preferential treatment by moving the registered office of a company to another EU member state.

However, the national legislations of EU member states are not identical and this may cause problems in the event of cross-border mergers. Certain EU member states incorporate into their legal order new legal statuses in order to avoid adherence to the EU directive on business combinations. In cases where member states have, in their own way, transposed Directive 2005/56/EC on cross-border mergers, commercial, accounting and sometimes even tax problems have continued or new such problems have arisen. The following problems relating to this issue may be considered as being the major ones: 
- Acquisition date determination versus the date of financial statements of the participating companies;

- The determination of the date of the merger coming into force;

- The above events occurring or not occurring on the same dates;

- The existence or non-existence of a duty to prepare special purpose financial reports as at the date preceding the date of acquisition;

- The existence or non-existence of a duty to re-measure the assets and liabilities of a liquidated company for the purpose of a merger - consolidation in the opening balance sheet of a legal successor;

- The form of reflecting the merger of companies and their businesses on the basis of:

- Consolidating the financial statements of the participating companies in the opening balance sheet of a legal successor;

- Accounting for the take over of individual items of assets and liabilities and items of equity in the accounting records of a legal successor.

For the purpose of both illustration and comparison, let's remind ourselves of the concept of the Czech national commercial and accounting legislation for domestic mergers under Act No. 125/2008 Coll., as amended, which includes the concept under which:

a) The acquisition date of a merger for domestic mergers is agreed. This date is in fact at the beginning of the whole process of a merger transaction. This is the date as at which all financial information (audited) is available based on which the participating companies may agree an amount and a structure of the equity of a legal successor, i.e. to agree on the shareholders' shares of power in a legal successor and, simultaneously, to agree that since this date, the economic activity of the participating companies will be considered the economic activity on behalf of the legal successor;

b) In addition to the keeping of accounting records of so far legally independent companies, it is essential that the conditions be secured to reflect in the accounting records the economic activity on behalf of a legal successor since the date of acquisition, i.e. by preparing an opening balance sheet as at the date of acquisition which, in fact, represents the "consolidated balance sheet" of the participating companies as at the date of acquisition; 
c) A merger project (in fact, a contract of merger) becomes effective only by registering the merger at the Commercial Court in charge of the Register of Companies on condition that before the contract is filed with the competent Commercial Court the notary public shall confirm that the participating companies have performed all of the acts stipulated by law. After a merger project is approved by the shareholders' meetings, the proposal for an entry in the Register of Companies shall be filed within 12 months since the date of acquisition. As a result, the date of an entry in the Commercial Register differs from the date of acquisition and the difference may be not only less but also more than 12 months. In addition, the fact of becoming effective also confirms the validity of the date of acquisition since which the economic activity of the participating companies is considered the economic activity on behalf of a legal successor.

d) The above stated act requires that for the purpose of a merger by the amalgamation of stock corporations the re-measurement of the business assets of the liquidated company shall take place so that within the new measurement these business assets (i.e. the assets and liabilities) shall be incorporated in the opening balance sheet of the legal successor. This requirement is reflected by Sec. 27 of Accounting Act No. 563/1991 Coll. This section stipulates that assets and liabilities be measured at fair value.

e) Both the Transformation Act and the Accounting Act assume that this new measurement of assets and liabilities for a legal successor takes place within the special purpose financial reports of a liquidated company as at the date preceeding the date of acquisition.

f) The Accounting Act and relating subordinate legislation stipulate how the gains of a re-measurement of assets and liabilities to obtain fair values will be accounted for in the equity and which cases will be accounted for immediately in the profit or loss and which will be accounted for in the balance sheet, i.e. in the individual items of equity - gains of new measurement - which has the following two variations: gains of new measurement of assets and liabilities and gains of new measurement on transformation. 
g) Sec. 24(3)(a) of the Accounting Act, however, allows for the measurement for the purpose of transformation that the measurement of a liquidated company is effected as for a whole, and for individual items of assets and liabilities the following two variations of measurement are allowed:

- Book values as stated in the accounting records of a liquidated company are used;

- New measurement of assets to current value and no measurement of liabilities to current value takes place.

h) As a consequence, both the special purpose financial reports of a liquidated company and the opening balance sheet of a legal successor, which is de facto a "consolidated balance sheet", include not only the items of assets, liabilities and equity of the legal successor but also the items of assets and liabilities of the liquidated company and the equity of the liquidated company affected by the method used to express new measurement to fair value. Since the Accounting Act stipulates two measurement methods for the purpose of transformation, including mergers, both the content and the structure of the information in both the special purpose financial reports and an opening balance sheet of a legal successor may be structured in various ways.

These consequences of Czech legislation, particularly of the Accounting Act, may be generally expressed in the tables set out below which, in the form of a balance sheet, show both the content and the structure of the accounting information in the special purpose financial reports of a liquidated company which, in principle, is transferred to the legal successor. The consequences for equity under Regulation 500/2002 Coll., as amended, are not presented in more detail, i.e. any influence of the fact that specific legislations specify whether new measurement of a certain asset or a liability should be accounted for in an income statement or in a balance sheet (see Sec. 51 - 54(a) of Regulation 500/2002 Coll., as amended) is not presented.

\section{The tables are as follows:}

Variation 1 - liquidated company, its assets and liabilities are measured at fair value under Sec. 27 of the Accounting Act and its net assets are measured as a sum of the fair values of the measured net assets. 
This approach is possible since the Transformations of Business Companies and Cooperatives Act does not specify a method of measurement to be used by an expert.

Variation 1a - the measurement of net business assets and the measurement of net assets are identical - general accounting method for a purchase expressed in the form of a balance sheet

Tab. 1: Variation 1a - Acquirer's balance sheet (for the acquirer)

\begin{tabular}{|c|c|c|c|}
\hline \multicolumn{2}{|l|}{ Assets } & \multicolumn{2}{|l|}{ Liabilities } \\
\hline $\begin{array}{l}\text { Assets in the original } \\
\text { book value }\end{array}$ & 2,000 & $\begin{array}{l}\text { Total cost of the business } \\
\text { acquired of which: } \\
\text { - equity-net assets } \\
\text { in book value } \\
\text { - difference of } \\
\text { measurement of assets } \\
\text { - difference of } \\
\text { measurement of } \\
\text { liabilities }\end{array}$ & $\begin{array}{r}1,700 \\
{[1,000} \\
+ \\
500 \\
+ \\
200]\end{array}$ \\
\hline $\begin{array}{l}\text { Re-measurement to fair } \\
\text { value }\end{array}$ & +500 & $\begin{array}{l}\text { Liabilities in original } \\
\text { book values }\end{array}$ & 1,000 \\
\hline & & $\begin{array}{l}\text { Re-measurement to fair } \\
\text { value }\end{array}$ & -200 \\
\hline Total assets in fair value & 2,500 & $\begin{array}{l}\text { Total liabilities in fair } \\
\text { value }\end{array}$ & 800 \\
\hline Total assets & 2,500 & Total liabilities & 2,500 \\
\hline
\end{tabular}

The numbers in brackets show an internal structure which, however, remains hidden.

Variation 1b - the measurement of net business assets based on business measurement/appraisal and the measurement of items of net assets to fair value are, if the totals are compared, different 
Tab. 2: Variation 1b - Acquirer's balance sheet (for the acquirer)

\begin{tabular}{|c|c|c|c|}
\hline \multicolumn{2}{|l|}{ Assets } & \multicolumn{2}{|l|}{ Liabilities } \\
\hline $\begin{array}{l}\text { Assets in the original } \\
\text { book value }\end{array}$ & 2,000 & $\begin{array}{l}\text { Total cost of the business } \\
\text { acquired of which: } \\
\text { - equity-net assets } \\
\text { in book value } \\
\text { - difference of } \\
\text { measurement of assets } \\
\text { - difference of } \\
\text { measurement of } \\
\text { liabilities } \\
\text { - recognition of other } \\
\text { shares assets which } \\
\text { cannot be recognised } \\
\text { separately }\end{array}$ & $\begin{array}{r}1,900 \\
{[1,000} \\
+ \\
500 \\
+ \\
200 \\
+ \\
200]\end{array}$ \\
\hline $\begin{array}{l}\text { Re-measurement to fair } \\
\text { value }\end{array}$ & +500 & $\begin{array}{l}\text { Liabilities in original } \\
\text { book values }\end{array}$ & 1,000 \\
\hline Goodwill & 200 & $\begin{array}{l}\text { Re-measurement to fair } \\
\text { value }\end{array}$ & -200 \\
\hline Total assets in fair value & 2,500 & $\begin{array}{l}\text { Total liabilities in fair } \\
\text { value }\end{array}$ & 800 \\
\hline Total assets & 2,700 & Total liabilities & 2,700 \\
\hline
\end{tabular}

In principle, this variation corresponds to a general purchase method stipulated by IAS/IFRS.

Variation 2-liquidated company - its business is measured/appraised as a whole and individual items of net assets of the liquidated company are measured under Sec. 24(3)(a):

Variation 2a - liquidated company - its business is measured/ appraised as a whole and the individual assets and liabilities which make up the net assets are measured in original book values stated in the accounting records of the accounting units which transfer the business to the acquirer [Sec. 24(3)(a)(1)]. 
Tab. 3: Variation 2a - Acquirer's balance sheet (for the acquirer)

\begin{tabular}{|c|c|c|c|}
\hline \multicolumn{2}{|l|}{ Assets } & \multicolumn{2}{|l|}{ Liabilities } \\
\hline $\begin{array}{l}\text { Assets in the original } \\
\text { book value }\end{array}$ & 2,000 & $\begin{array}{l}\text { Total cost of the business } \\
\text { acquired of which: } \\
\text { - equity-net assets } \\
\text { in book value } \\
\text { - difference of } \\
\text { measurement of assets } \\
\text { - difference of } \\
\text { measurement of } \\
\text { liabilities } \\
\text { - new assets which cannot } \\
\text { be distinguished } \\
\text { separately }\end{array}$ & $\begin{array}{r}1,900 \\
{[1,000} \\
+ \\
500 \\
+ \\
200 \\
+ \\
200]\end{array}$ \\
\hline $\begin{array}{l}\text { Difference of } \\
\text { measurement of acquired } \\
\text { assets }\end{array}$ & +900 & $\begin{array}{l}\text { Liabilities in original } \\
\text { book values }\end{array}$ & 1,000 \\
\hline $\begin{array}{l}\text { Original value of total } \\
\text { assets }\end{array}$ & 2,000 & $\begin{array}{l}\text { Original value of total } \\
\text { liabilities }\end{array}$ & 1,000 \\
\hline Total assets & 2,900 & Total liabilities & 2,900 \\
\hline
\end{tabular}

The value of the difference of measurement of the assets acquired (see Sec. 7(10) of Regulation 500/2002 Coll., as amended) includes the values of cost differences between the original book value of assets and liabilities from the accounting records of the assigning accounting unit and their fair value and, further, the value of newly recognised assets or net assets included in the total cost of the business acquired.

Variation $\mathbf{2 b}$ - liquidated company - its business is measured/appraised as a whole and individual items of assets are re-measured under Sec. 24(3)(a)(2), the items of liabilities are not re-measured. 
Tab. 4: Variation 2b - Acquirer's balance sheet (for the acquirer)

\begin{tabular}{|c|c|c|c|}
\hline \multicolumn{2}{|l|}{ Assets } & \multicolumn{2}{|l|}{ Liabilities } \\
\hline $\begin{array}{l}\text { Assets in the original } \\
\text { book value }\end{array}$ & 2,000 & $\begin{array}{l}\text { Total cost of the business } \\
\text { acquired of which: } \\
\text { - equity-net assets } \\
\text { in book value } \\
\text { - difference of } \\
\text { measurement of assets } \\
\text { - difference of } \\
\text { measurement of } \\
\text { liabilities } \\
\text { - recognition of other } \\
\text { shares assets which } \\
\text { cannot be recognised } \\
\text { separately }\end{array}$ & $\begin{array}{r}1,900 \\
{[1,000} \\
+ \\
500 \\
+ \\
200 \\
+ \\
200]\end{array}$ \\
\hline $\begin{array}{l}\text { Re-measurement to fair } \\
\text { value }\end{array}$ & +500 & $\begin{array}{l}\text { Liabilities in original } \\
\text { book values }\end{array}$ & 1,000 \\
\hline Goodwill & 400 & $\begin{array}{l}\text { Re-measurement to fair } \\
\text { value }\end{array}$ & 0 \\
\hline Total assets in fair value & 2,500 & $\begin{array}{l}\text { Total liabilities in fair } \\
\text { value }\end{array}$ & - \\
\hline Total assets & 2,900 & Total liabilities & 2,900 \\
\hline
\end{tabular}

The value of the newly recognised goodwill (see Sec. 6(3)(d) of Regulation 500/2002 Coll., as amended) differs from the value of the goodwill in variation $1 \mathrm{~b}$, since, in its essence, in addition to the goodwill carried at fair value of the acquired business, it also includes the cost difference between the fair value of the acquired liabilities and their original book values.

In the event of cross-border mergers, if a legal successor has its registered office in the Czech Republic, variation 2a is in fact offered. This variation is relied on particularly when a liquidated company is moving from a EU member state which does not require or directly does not allow for an asset and liability measurement in connection with mergers. In this event Act No. 126/2008 Coll., in PART THREE Change in the Accounting Act, Article IV(3) assumes that a re-measurement is performed only for an opening balance sheet under the model 2 a stated above. In the past, this model was not unusual when businesses were 
merging. A difference of measurement - a difference of re-measurement was in the past also applied in the USA under APB Opinion 16 in which it was recognised that a difference of valuation includes: a) the increase in value from re-measurement, b) goodwill - the remaining segment after an increase in value from re-measurement is deducted. Germany also recognised and used the "Buchwertsmethode" and "Neubewertungsmethode" methods, where the first method compared a total purchase price of a business with the acquired net assets in the original book values.

If we generally work with the stipulations of Regulation (EC) No. 1606/2002 of the European Parliament and of the Council on the application of international accounting standards as EU directives, then also an acquisition method included in IFRS 3 Business combinations of 2008 could be considered.

Below is the variation corresponding with a general acquisition method under IFRS 3 as amended in 2008, which is worth considering particularly for capital mergers, however, its application for mergers in general might be also considered:

$80 \%$ share of equity of a controlled company was acquired for $\quad 1,900$

For non-controlling $20 \%$ share if the price is the same

Fair value of the acquired $80 \%$ share is measured at

All net assets measured at fair value total

1,700

Total goodwill (2 $375-1700)$

675

Of which goodwill paid $(1900-0,8 \cdot 1700)$ 
Tab. 5: Acquirer's balance sheet (for the acquirer)

\begin{tabular}{|c|c|c|c|}
\hline \multicolumn{2}{|l|}{ Assets } & \multicolumn{2}{|l|}{ Liabilities } \\
\hline $\begin{array}{l}\text { Assets in the original } \\
\text { book value }\end{array}$ & 2,000 & $\begin{array}{l}\text { Total cost of the business } \\
\text { acquired of which: } \\
\text { Total in fair value of } \\
\text { which } \\
\\
\text { - equity-net assets } \\
\text { in book value } \\
\text { - difference of } \\
\text { measurement of assets } \\
\text { - difference of } \\
\text { measurement of } \\
\text { liabilities } \\
\text { - recognition of other } \\
\text { shares assets which } \\
\text { cannot be recognised } \\
\text { separately }\end{array}$ & $\begin{array}{r}1,900 \\
-80 \% \\
+475- \\
20 \% \\
2,375- \\
100 \% \\
{[1,000} \\
+ \\
500 \\
+ \\
200 \\
+ \\
675]\end{array}$ \\
\hline $\begin{array}{l}\text { Re-measurement to fair } \\
\text { value }\end{array}$ & +500 & $\begin{array}{l}\text { Liabilities in original } \\
\text { book values }\end{array}$ & 1,000 \\
\hline $\begin{array}{l}\text { Total goodwill } \\
\text { of which } \\
\begin{array}{l}- \text { paid } \\
- \text { not paid }\end{array}\end{array}$ & $\begin{array}{r}400 \\
{[540} \\
135]\end{array}$ & $\begin{array}{l}\text { Re-measurement to fair } \\
\text { value }\end{array}$ & -200 \\
\hline Total assets in fair value & 3,175 & $\begin{array}{l}\text { Total liabilities in fair } \\
\text { value }\end{array}$ & 800 \\
\hline Total assets & 3,175 & Total liabilities & 3,175 \\
\hline
\end{tabular}

As it can be seen, the process of a measurement and reporting of the net assets acquired within domestic mergers under Czech legislation is rather questionable. The right of choice is considerable and the choice of the procedure according to the variations possible under the legislation both makes achieving a true and fair view in financial accounting more difficult and creates a space for interest groups' solutions.

Where cross-border mergers are concerned the following two situations may occur: 
a) The national legislation in the EU member state has a similar concept as in the Czech Republic. In this event, the assets and liabilities of the liquidated foreign company are transferred as re-measured within a cross-border merger with a Czech business company with the registered office in the Czech Republic. Then it is a question as to whether the re-measurement took place according to similar rules.

b) If national legislation in another EU member state does not allow for re-measurement, then the assets and liabilities of the liquidated foreign company are re-measured in an opening balance sheet of the legal successor with reference to Sec. 24(3)(a)(1) of Czech accounting act. In other words, de facto the business of the liquidated company will be re-measured and individual assets and liabilities will be taken over by the legal successor in original book values and it is possible that currency will be translated from EUR or the national currency of the state from which the business comes from to CZK. The issue of the translation to Czech currency might be complicated by whether or not special purpose financial reports are prepared under the national legislation of the liquidated company, and if so, at which date.

In other words, in addition to the problem of a possible measurement of assets and liabilities which a Czech legal successor takes over from the foreign liquidated company, there is another problem in the relationship between the date of acquisition or the dates of financial statements and the date of the entry in the Register of Companies. Directive 2005/56/EC of the European Parliament and of the Council of 26 October 2005 on cross-border mergers of limited liability companies mentions the dates of financial statements and subsequently also the Czech Act regulating Transformations of Business Companies and Cooperatives in Sec. 181 refers to the date of financial statements which is stated in the project and serves the purpose of determining the conditions for cross-border mergers. In my opinion, this provision of the European directive in particular causes the situation where national legislations of member states are not uniform in their understanding of the date of acquisition.

This means that certain member states have a similar model as Czech legislation, i.e. they recognise not only the date of acquisition at the beginning of the process of a cross-border merger since which economic activities are carried out on behalf of the legal successor and at which financial values agreed in the project are determined (an amount and structure of the equity of the liquidated company, a measurement of assets 
and liabilities being taken over) but also the initial situation in an opening balance sheet of the later recognised legal successor.

Other member states understand the issue of the date of acquisition differently and tie this date with the date of the entry of a merger in the Register of Companies. This date, i.e. when the transaction becomes effective, is considered the date of acquisition. In my opinion, one principal problem is associated with this model of understanding the date of acquisition, since a merger process is very complicated in terms of agreeing the values to be stated in the project, and this process of agreeing must in reality take place before an entry in the appropriate public register is made. As a result, several months must elapse between the date of obtaining real and corresponding financial information and the entry in the Register of Companies. This financial information, naturally, is not valid as at the date of entry in the Register of Companies since the participating companies could not have interrupted their business activities. As a result, the originally agreed financial values are different as at the date of the entry in the Register of Companies and the date of becoming effective. A problem then arises as to what to do with the differences resulting from the passage of time. This situation has been experienced by Czech accounting already before 2002, when the so called allowance for acquired assets existed (as part of non-current assets or their long-term adjustment) to express these differences. The economic interpretation of this allowance was rather questionable. It could have included the following:

- The difference of measurement between book and fair values of individual assets and liabilities;

- Goodwill or badwill or profit from a fortunate purchase;

- In fact, even a profit or loss for the period from the preparation of the proposal of a merger project until the date of registration of the approved project when the merger becomes effective.

The allowance's 15 year straight-line depreciation resulted in longterm influence on the profit or loss of a legal successor.

As a result, the model of the date of acquisition as at the date when all current financial information is available and which precedes the date of an entry in the Register of Companies and thus also the legal effect of a merger, expresses the actual course of a merger in a better and more credible way (though it is done retrospectively from the point of view of 
an entry in the Register of Companies). In particular, it prevents the financial profit or loss of the participating companies for the period from the project preparation until the date of an entry in the Register of Companies ending up in some sort of allowance to the acquired business and then being depreciated again in the profit or loss. The significance of the concept with the preceding date of acquisition is considerable since, otherwise, an allowance to acquired assets is material (i.e. significant in terms of value from the point of view of financial management and decision-making). As a result, I am of the opinion, that the variation with the identical date of acquisition and the date of entry in the Register of Companies leads to the misstatement of the financial situation of a legal successor reported in financial statements both as at the date of an entry of a merger in the Register of Companies and subsequently, for the period of several years (e.g. 15 years).

In association with this outlook on the date of acquisition, the problem of the so called special purpose financial reports usually also comes into consideration. Under the Act regulating Transformations of Business Companies and Cooperatives, special purpose financial reports are financial statements prepared by the participating companies as at the date which precedes the date of acquisition (see Sec. 11 of the Czech Act regulating Transformations of Business Companies and Cooperatives). The purpose of these financial statements is both to provide summary and, at least by detailed review, verified information on the assets, liabilities and business substance of the participating companies and to represent a basis for the consolidation of the assets, liabilities and equity in the opening balance sheet of the legal successor. These financial statements serve as a tool for documenting the division of the handed over power and responsibility for all items of net assets handed over from a liquidated company to a legal successor and also for an amount of equity handed over from a liquidated company and merged with the equity of a legal successor (which is particularly important since it creates a basis for the controlling and power structure of a legal successor).

The significance of special purpose financial reports as a bearer of real, adequate information based on which a corresponding agreement will exist in the project as at the date of acquisition is thus considerable. As a result, special purpose financial reports dated only before the date of an entry in the Register of Companies are questionable, since they can be hardly credibly prepared as a basis for a take over as at the date of the entry in the Register of Companies should a real take over of assets and 
power precede the entry of a merger in the Register of Companies. In order for a lack of evidence of accounting information to be prevented and thus also any potential manipulation with it, special purpose financial reports should be prepared as at the date preceding the date of acquisition. As to the quality, they should be of the nature of ordinary or extraordinary financial statements (in the spirit of the Czech Accounting Act).

Another problem of special purpose financial reports might be the issue of asset and liability re-measurement. This is supposed to be effected within special purpose financial reports as an entry in the consolidation for an opening balance sheet or only within an opening balance sheet in the process of consolidation. With regard to the actual substance of both domestic and cross-border mergers, which involves a general purchase contract, a re-measurement should be effected only within the consolidation of an opening balance sheet. If special purpose financial reports are perceived as being a specially prepared entry in the consolidation for an opening balance sheet, then the new measurement could be included already in these special purpose financial reports. However, a problem may arise in special purpose financial reports since they may include deferred tax, assumed goodwill or a difference of measurement to the acquired assets. I would prefer a variation within which re-measurement and related deferred tax and even more recognition of the "difference of the reception of a business" an opening balance sheet of the legal successor only.

In the case of cross-border mergers where a foreign legal successor is concerned, some national legislations do not require that an opening balance sheet be prepared. This means, in principle, that a foreign legal successor does not consolidate the financial statements of the participating companies, and the merger is effected based on accounting transactions which are analogical to the transaction of a contribution of a business. Often, this may be associated with the fact that the foreign participating company does not even prepare special purpose financial reports. This, probably, is a matter of habit and reliance on the sufficient reliability of accounting information. In other words, less pressure is put on the provability of transferred and received assets, liabilities and the

\footnotetext{
1 In this material, the term "difference of the reception of a business" is used as a general term for various types of consolidation differences, goodwills, differences of valuation to acquired assets (business), i.e. not in the sense stipulated in Regulation No. 500/2002 Coll., as amended, Sec. 14(a) "difference of the transformation of a business".
} 
shares of shareholders of a liquidated company. In my opinion, joining companies by way of mergers, particularly cross-border mergers, on the basis of consolidation of financial statements puts much pressure on the process of securing a true and fair view in accordance with verified and provable accounting information. This fact is, in my opinion, significant in relation to the transfer of powers and responsibilities from a liquidated company to the legal successor.

\section{Conclusion}

It is noticeable that both the legal and accounting conceptual differences may exist quite often in spite of the unification processes taking place via the transposition of EU directives into national law. The most common differences can be summarised as follows:

1. If there is a re-measurement or no re-measurement during mergers, and where re-measurement is required, the manner of its reflection in the accounting records in accordance with national regulations, modification of a general accounting method used for a purchase;

2. The date of acquisition (balance sheet date) versus the date of coming into force by means of an entry in the prescribed register;

3. The existence or non-existence of a duty to prepare special purpose financial reports whose consolidation is used to determine values in the opening balance sheet of the legal successor of a merger of the businesses of the participating companies;

4. The determination of an opening balance sheet by consolidating the special purpose financial reports of the participating companies, but technically - by means of accounting entries by which the successor takes over the business of a liquidated company and its assets and liabilities, i.e. a de facto accounting procedure as used for booking the capital contributions of a business.

From a formally legal point of view, these discrepancies represent obstacles in implementing cross-border mergers. In my opinion, we should take into consideration a solution based on the direction implied already in the 1980's by International Accounting Standards, i.e. to understand both domestic and cross-border mergers as business combinations and to build both commercial law and accounting law for 
this area on the common concept whose expression is a de facto general accounting method used for purchases.

\section{References}

[1] Dvořák, T. (2008): Přeměny obchodních společností a družstev. (In English: Transformations of Business Companies and Cooperatives.) Praha, ASPI-Wolter Kulwer, 2008.

[2] Mařík M. (2004): Oceňování podniku pro fúze a akvizice - chyby a problémy. (In English: Business Measurement for Mergers and Acquisitions - Mistakes and Problems.) In: Sborník zodborné konference Přeměny společností s důrazem na přeshraniční fúze. (In English: Proceedings from the conference Company Transformations with Emphasis Put on Cross-border Mergers). Praha, Oeconomica, 2004.

[3] Pelák, J. (2006): Podnikové kombinace - komparační analýza. (In English: Business Combinations - A Comparative Analysis.) Praha, University of Economics, 2006, PhD. thesis.

[4] Skálová, J. (2010): Účetní, daňové a právní aspekty přeshraničních fúzí v Evropské Unii. (In English: The Accounting, Tax and Legal Aspects of Cross-border Mergers in the European Union.) Praha, University of Economics, 2010, PhD. thesis.

[5] Vomáčková, H. (2009): Účetnictví akvizicí, fúzí a jiných vlastnických transakcí. (In English: Accounting for Acquisitions, Mergers and Other Proprietary Transactions). Praha, Bova Polygon, 2009. 


\title{
Accounting for Cross-border Mergers and Its Problems
}

\author{
Hana VOMÁČKOVÁ
}

\begin{abstract}
Both the legal and accounting conceptual differences in national legislations regulating mergers may be quite significant in spite of the unification processes taking place via the transposition of EU directives into national law. Most often, we find differences in the following issues: If there is a re-measurement or no re-measurement during mergers, and where re-measurement is required, the manner of its reflection in the accounting records in accordance with national regulations, usually as a modification of a general accounting method used for a purchase; The date of acquisition (balance sheet date) versus the date of coming into force by means of an entry in the prescribed register; The existence or non-existence of a duty to prepare special purpose financial reports whose consolidation is used to determine values in the opening balance sheet of the legal successor of a merger of the businesses of the participating companies; The determination of an opening balance sheet by consolidating the special purpose financial reports or the participating companies, but - technically - by means of accounting entries by which the successor takes over the business of a liquidated company and its assets and liabilities, i.e. a de facto accounting procedure as used for booking the contribution of a business. From a formally legal point of view, these discrepancies represent obstacles in implementing crossborder mergers. If we do not take into consideration potentially inaccurate terminology arising from the translation of the EU directive regulating cross-border mergers, there is a solution based on the direction implied already in the 1980's by International Accounting Standards, i.e. to understand both domestic and cross-border mergers as business combinations and to build both commercial law and accounting law for this area on the common concept whose expression is a de facto general accounting method used for purchases.
\end{abstract}

Key words: Merger; Cross-border mergers; Date of acquisition; Date of balance sheet; Special purpose financial reports; Opening balance sheet; Measurement by merger; Fair value; Book value; Gains of new measurement; Goodwill; Difference of measurement.

JEL classification: M41. 